\title{
LA MICROBIOLOGÍA MÉDICA Y LAS ENFERMEDADES INFECCIOSAS EN EL CÓMIC
}

\section{Medical microbiology and infectious diseases and comics}

\author{
José Elías GARCÍA SÁNCHEZ; Enrique GARCÍA SÁNCHEZ \\ Departamento de Ciencias Biomédicas y del Diagnóstico. Facultad de Medicina. Universidad de Salamanca (España). \\ e-mail: joegas@usal.es
}

El cómic es una palabra inglesa aceptada por la RAE que lo define como una serie o secuencia de viñetas que cuenta una historia y también como el libro o revista que contiene cómics.

\section{Consideraciones previas}

En cuanto a la primera acepción de la RAE decir que es sinónimo de historieta, tebeo y noveno arte. Con relación a este último hay que señalar que puede ser obra de uno o varios autores y que es narrativo, empleando un lenguaje propio, muy cinematográfico. La calidad del dibujo y del guion son determinantes de la aceptación y utilización. Como en otras artes se pueden observar diversos estilos, tendencias, realización y géneros.

Explosiona en el siglo XX por la difusión y mejora de los medios impresos y en el siglo XXI ese puede acceder a él tanto en papel como por medios digitales utilizando diversos formatos, pdf, cbr o cbz, por ejemplo.

El comic es de disfrute individual, a diferencia del cine, puede ser muy reflexivo, como la literatura, permite la lectura y relectura amen de la discusión. Es un medio de comunicación de masas visual y actual, entretiene, informa, mentaliza y forma. Puede tratar cualquier tema. Es atractivo. En general sus historias no son largas y es conciso.
Ediciones Universidad de Salamanca / @ब(1)

[ 53 ]
En cuanto a la segunda acepción de la RAE es preciso señalar que hay distintos tipos de comics de prensa (páginas o fascículos tipo revista) como las tiras diarias (Daily) (conclusivas o continuará), dominicales (Sunday) (conclusivos o continuará) y suplementos dominicales, los comic book, recuérdese por ejemplo los de Superman, las novela gráfica (Graphic novel), Contrato con Dios de Will Eisner es una de ellas, cuadernillos (conclusivos o continuará), como los del Capitan Trueno, narrativa acompañada de su desarrollo en comic (Biografías, novelas, novelas populares, etc.), revistas (con historias conclusivas o continuará), állbumes (conclusivos o continuará) y sus recopilatorios, manga, ...

\section{El cómic y la educación}

Dado que el comic cuenta una historia y es medio de comunicación de masas visual es utilizable en trasmisión de información y de mensajes, por lo tanto, en educación a todos los niveles incluida la universitaria (grado, postgrado / master y doctorado), especialización y formación profesional continuada. Todo ello en diversas aéreas incluidas las biosanitarias (Medicina Gráfica) y en estas en distintos niveles, formación, divulgación, mentalización, sensibilización e información. El reflejo de la medicina en el comic y su utilización en enseñanza de 


\section{LA MICROBIOLOGÍA MÉDICA Y LAS ENFERMEDADES INFECCIOSAS EN EL CÓMIC JOSÉ ELÍAS GARCÍA SÁNCHEZ; ENRIQUE GARCÍA SÁNCHEZ}

la medicina no es nuevo, hay numerosas publicaciones en papel y electrónicas (libros, revistas, páginas web) que lo avalan (véase por ejemplo PubMed, Google, Google Académico, etc.).

El tema puede ser complicado, hay problemas como pueden ser: la limitación de temas, la dificultad de localizarlos (las bases de datos limitadas, no hay un imdb, un Filmaffinity o similares, habrá que recurrir en muchos casos a la lectura, PubMed, internet y no olvidar Tebeosfera, Graphic Medicine o Medicina Gráfica), disponer de ellos y en número suficiente (comerciales (donde hay que tener en cuenta el costo y la adquisición por parte de los centros) y gratuitos (pérdida de derechos de autor e instituciones, los comics educativos), el estar al tanto de los gustos de los destinatarios (Los comic como otros medios pueden parecer desfasados), y realizar material docente complementario.

\section{Microbiología médica y enfermedades infecciosas en el cómic}

Existen de varios temas, tanto menciones, presencias puntuales (a veces son el motor) del argumento, personajes enfermos, alegorías (rabia/zombis) y argumentales (muchos institucionales, lo que se demuestra su poder educativo,) Son muy numerosos en VIH/SIDA.

Su valor educativo variable, depende del guion (especialistas), dibujo, gustos, idioma u obsolescencia.

El objetivo de este trabajo es localizarlos, en bastantes temas muchos de los modernos, son no comerciales, gratuitos y divulgativos para enseñanza no universitaria.

Se han encontrado y consultado comics sobre Antimicrobianos, Bacterias, Cólera, Dengue, Difteria, Disenteria, Dracunculiasis, Ébola, Enfermedad de Chagas, Enfermedad de Lyme, Enfermedad del sueño, Esquistosomiasis, Fiebre amarilla, Filarias, Gripe, Guerra biológica , Hepatitis A, B, C, Historia, Hongos, Infecciones ficticias, ITS, Lepra, Malaria, Papilomavirus, Parásitos, Peste, Rabia, Polio, Rubeola, Sarampión, Sida y VIH, Sífilis, Tuberculosis, Vacunas, Viruela y Virus.

Resumen de la ponencia presentada en la Reunión científica La Revista de Medicina y Cine en los estudios de Ciencias de la Salud el día 7 de noviembre de 2019, en el marco del XXIV Congreso de la Sociedad Española de Educación Médica y V Congreso Hispano-Luso, celebrado en Salamanca del 6 al 8 de noviembre de 2019. 